\title{
Pengungkapan Emisi Karbon: Menguji Peranan Tipe Industri, Kinerja Lingkungan, Karakteristik Perusahaan dan Komite Audit
}

\author{
Nur Widhya Tyas Saptiwi \\ Universitas Katolik Soegijapranata \\ tyassaptiwi@gmail.com
}

\begin{abstract}
Abstrak
Wacana tentang perubahan iklim dan pemanasan global dalam beberapa dekade terakhir telah menimbulkan kegelisahan dikalangan masyarakat dan dunis bisnis di seluruh dunia. Salah satu penyebabnya adalah pembuangan emisi karbon yang tidak terkendali. Upaya tiap-tiap negara untuk meningkatkan pertumbuhan ekonomi melalui industrialisasi turub memperburuk iklim global. Karena itu, perlu gerakan global untuk mengantisipasi perubahan iklim yang dapat mengancam kelangsungan umat manusia. Penelitian ini bertujuan untuk menguji pengaruh tipe industri, kinerja lingkungan, karakteristik perusahaan (profitabilitas, leverage, ukuran perusahaan) dan komite audit terhadap pengungkapan emisi karbon pada perusahaan-perusahaan yang terdaftar di Bursa Efek Indonesia (BEI) periode tahun 2012-2016. Sampel diambil dengan menggunakan tehnik purposive sampling dan menghasilkan 117 perusahaan yang dapat digunakan untuk pengujian hipotesis. Analisis regresi menunjukkan kinerja lingkungan, ukuran perusahaan dan komite audit berpengaruh positif terhadap pengungkapan emisi karbon. Tipe industri dan profitabilitas berpengaruh negatif terhadap pengungkapan emisi karbon. Sedangkan leverage tidak berpengaruh terhadap pengungkapan emisi karbon.
\end{abstract}

Kata kunci: tipe industri, kinerja lingkungan, karakteristik perusahaan, komite audit, pengungkapan emisi karbon.

\begin{abstract}
Discourse on climate change and global warming in the last few decades has caused unrest among people and business world around the world. One reason is the uncontrolled disposal of carbon emissions. The efforts of each country to increase economic growth through the industrialization of turub worsen the global climate. Therefore, a global movement is needed to anticipate climate change that can threaten the survival of humanity. This study aims to examine the effect of industry type, environmental performance, company characteristics (profitability, leverage, company size) and audit committee on the disclosure of carbon emissions in companies listed on the Indonesia Stock Exchange (IDX) for the period 20122016. Samples were taken using purposive sampling techniques and produced 117 companies that can be used for hypothesis testing. Regression analysis results show that environmental performance, company size and audit committee have a positive effect on disclosure of carbon emissions. Meanwhile, industry type and profitability negatively affect the disclosure of carbon emissions, while leverage does not affect the disclosure of carbon emissions.
\end{abstract}

Keywords: Industry Type, Environmental Performance, Firm Characteristics, Carbon Emission Disclosure. 


\section{PENDAHULUAN}

Terjadinya kerusakan lingkungan dan krisis sosial-lingkungan yang dirasakan oleh masyarakat di berbagai negara semakin hari terus meningkat (Budianta, 2010). Perilaku manusia yang tidak ramah lingkungan dengan mengeksploitasi sumber daya alam akan memperburuk sumber daya lingkungan. Sementara itu, isu perubahan iklim dan pemanasan global menjadi tren dengan berkembangnya dunia industri. Lajunya perkembangan industri di berbagai negara yang berdampak mempercepat laju perekonomian di dunia. Di sisi lain memberikan efek negatif sejalan dengan berkembangnya industri yakni semakin menurunnya kualitas lingkungan dan meningkatnya emisi gas rumah kaca.

Salah satu penyebab peristiwa yang terkait dengan perubahan iklim dan penurunan lingkungan yakni kebakaran lahan di kepulauan Riau pada tahun 2016, kebakaran gambut di Kalimantan dan Sumatera di tahun 2015. Salah satu penyimpanan karbon dunia kini semakin menurun seiring dengan kerusakan hutan dan hancurnya lahan gambut di kawasan tropis di Indonesia akibat konversi lahan menjadi perkebunan kelapa sawit dan industri kertas (Pratiwi dan Sari, 2016). Lahan gambut Indonesia menjadi salah satu sumber utama emisi karbon dunia atas peristiwa hancurnya lahan dan berkurangnya cadangan karbon dunia.Dari peristiwa tersebut, menjadi refleksi bagi perusahaan-perusahaan untuk koreksi terhadap sistem dan praktik perekonomian Indonesia yang selama ini berjalan yakni pendekatan bisnis konvensional yang hanya mengutamakan kepentingan ekonomi saja tanpa memikirkan lingkungan sekitar yang telah membawa dampak menurunnya kualitas lingkungan.

Menurut Irwhantoko (2016) gerakan masyarakat internasional dalam menangani isu-isu tentang pemanasan global dan perubahan iklim agar berkurangnya emisi karbon dimulai sejak munculnya Protokol Kyoto pada tahun 1997 yang diadakan di Kyoto, Jepang.Beberapa negara telah menandatangani dan meratifikasi Protokol Kyoto tersebut atas kepedulian mereka terhadap lingkungan dan kondisi pembangunan yang tidak hanya berfokus pada pertumbuhan ekonomi saja melainkan juga tanggung jawab sosial termasuk lingkungan.Salah satu negara yang telah meratifikasi yakni Indonesia yang tercantum dalam Undang-Undang Nomor 17 Tahun 2004 dalam rangka dilaksanakannya pembangunan berkelanjutan serta ikut serta dalam upaya penurunan emisi gas rumah kaca global.

Menurut Jannah dan Muid (2014), komitmen Indonesia untuk mengurangi emisi karbon dapat dilihat dari adanya Perpres Nomor 61 Tahun 2011 dan Perpres Nomor 71 Tahun 2011, di dalam pasal 4 Perpres Nomor 61 Tahun 2011 dijelaskan bahwa perusahaan atau pelaku usaha ikut andil dalam upaya penurunan emisi gas rumah kaca (termasuk emisi karbon) yang dilakukan oleh perusahaan dengan melakukan pengungkapan emisi karbon (Carbon Emission Disclosure).

Perusahaan yang melakukan pengungkapan atas aktivitas operasionalnya akan dapat diterima oleh masyarakat maupun para stakeholdernya. Bersamaan dengan hal itu, berkembangnya industri yang pesat dengan berbagai macam tipe industri yang ada di Indonesia, terdapat perusahaan yang masuk ke dalam golongan intensif untuk perihal hasil karbon. Masyarakat yang memberikan tekanan besar terhadap perusahaan tersebut membuat perusahaan intensif berpeluang tinggi dalam melaksanakan pengungkapan emisi karbon apabila dibandingkan dengan perusahaan non intensif. Perusahaan yang melakukan pengungkapan emisi karbon sebagian besar dari industri yang aktivitas operasionalnya berpengaruh tinggi terhadap lingkungan. Pentingnya pengungkapan emisi karbon menjadi motivasi yang mendorong penelitian ini. Secara spesifik ada lima faktor yang akan diuji dampaknya terhadap pengungkapan emisi karbon yaitu tipe industri, kinerja lingkungan, karakteristik perusahaan (profitabilitas dan tingkat utang), dan Komite Audit. 


\section{TINJAUAN LITERATUR DAN PERUMUSAN HIPOTESIS}

\section{Tipe Industri dan Pengungkapan Emisi Karbon}

Industri yang menjadi sorotan publik adalah industri-industri yang operasi bisnisnya menghasilkan tingkat emisi karbon yang tinggi dan tingkat pencemaran lingkungan yang tinggi pula. Menurut Prafitri dan Zulaikha (2016)tidak semua perusahaan yang bergerak di berbagai bidang memberikan informasi mengenai aktivitasnya jika tidak memiliki nilai positif bagi perusahaan tersebut. Jenis perusahaan yang intensif karbon adalah pertambangan, energi dan manufaktur, serta industri dasar dan kimia.

Dalam penelitian yang dilakukan oleh Van De Burgwal dan Vieira (2014) dalam Nugraha (2015) menjelaskan bahwa perusahaan yang mempunyai dampak lingkungan lebih tinggi harus melaporkan informasi yang lebih banyak daripada perusahaan yang memiliki dampak lingkungan yang rendah. Menurut Choi et al. (2013) dalam Jannah dan Muid (2014) tingkat pengungkapan emisi karbon secara sukarela akan lebih besar pada perusahaan yang intensif dalam menghasilkan emisi seperti energi, transportasi, materials dan utilitas. Dengan demikian, perusahaan yang tinggi dalam menghasilkan emisi karbon akan cenderung melakukan pengungkapan informasi mengenai emisi karbonnya. Pengungkapan informasi mengenai emisi karbon yang dilakukan oleh perusahaan intensif karbon akan membantu perusahaan dalam memperoleh legitimasi dari masyarakat dan sebagai bentuk pertanggungjawaban perusahaan terhadap stakeholder. Berdasarkan uraian diatas dapat dirumuskan hipotesis sebagai berikut :

\section{H1: Tipe industri berpengaruh positif terhadap pengungkapan emisi karbon.}

\section{Kinerja Lingkungan dan Pengungkapan Emisi Karbon}

Penelitian yang dilakukan Dawkins dan Fraas(2011) menunjukkan bahwa kinerja lingkungan memiliki hubungan positif terhadap pengungkapan lingkungan yakni terkait emisi gas rumah kaca yang didalamnya termasuk emisi karbon. Perusahaan dengan kinerja lingkungan yang rendah tidak akan mengungkapkan informasi untuk penghindaran dari paparan negatif, sedangkan perusahaan dengan kinerja lingkungan yang baik akan membedakan diri dengan mengungkapkan informasi secara sukarela mengenai kinerja perusahaan mereka. Informasi yang diungkapkan oleh perusahaan dapat memberikan keuntungan bagi perusahaan karena dapat meningkatkan nilai perusahaan. Sejalan dengan penelitian Luo et al. (2013) dalam Prafitri dan Zulaikha (2016) yang menyatakan bahwa perusahaan dengan kinerja karbon yang baik akan cenderung untuk menyampaikan laporan mengenai pengungkapan emisi karbon.

Adanya kinerja lingkungan yang baik dapat membuat perusahaan memberikan jaminan bagi publik bahwa perusahaan telah berkontribusi dalam pengurangan dampak perubahan iklim dan berusaha dalam meminimalisasi terjadinya pemanasan global(Anggraeni, 2015). Perusahaan dengan kinerja lingkungan yang baik akan memberikan informasi kinerja lingkungannya dalam bentuk pengungkapan lingkungan, dalam hal ini pengungkapan emisi karbon. Hal tersebut dapat menunjukkan komitmen perusahaan terhadap lingkungan agar mendapat dukungan dari para stakeholder dan legitimasi dari masyarakat (Lu dan Abeysekara, 2012) dalam Majid (2015). Berdasarkan uraian tersebut maka dirumuskan hipotesis sebagai berikut:

H2: Kinerja lingkungan berpengaruh positif terhadap pengungkapan emisi karbon. 


\section{Profitabilitas dan Pengungkapan Emisi Karbon}

Perusahaan yang kondisi keuangannya baik akan lebih memungkinkan melakukan pengungkapan informasi lingkungan. Menurut Nugraha (2015) profitabilitas adalah kemampuan perusahaan dalam memperoleh laba atau profit. Penelitian Pradini (2013) menjelaskan bahwa perusahaan yang kemampuan kinerja keuangannya lebih baik maka akan semakin besar kemungkinan perusahaan untuk melakukan pengurangan emisi dari aktivitas perusahaannya. Kemampuan kinerja keuangan perusahaan dalam keikutsertaannya untuk upaya penurunan emisi karbon seperti digantinya mesin-mesin yang lebih ramah lingkungan, atau tindakan lingkungan lainnya seperti melakukan gerakan penanaman 1000 pohon.

Menurut Choi et al. (2013) dalam Jannah dan Muid(2014) perusahaan yang kondisi keuangannya baik dapat membiayai sumber daya tambahan manusia atau finansial yang dibutuhkan untuk laporan pengungkapan emisi karbon yang lebih baik guna mencegah tekanan dan tuntutan eksternal. Perusahaan yang profitabilitasnya tinggi akan melakukan pengungkapan informasi dan didapatnya sinyal bahwa perusahaan dapat bertindak baik mengenai tuntutan lingkungan secara efektif dan siap untuk menyelesaikan masalah dengan cepat.

Menurut Clarkson et al. (2008) perusahaan yang menghasilkan keuntungan yang lebih memungkinkan untuk melakukan pengungkapan lingkungannya. Dan menurut Luo et al. (2013) dalam Prafitri dan Zulaikha (2016) perusahaan yang kinerja keuangannya baik memiliki kemampuan secara finansial dalam melakukan keputusan terkait lingkungan. Sedangkan perusahaan dengan kinerja keuangan yang buruk akan lebih fokus untuk mencapai tujuan keuangan dan meningkatkan kinerja perusahaan sehingga adanya batasan kemampuan dalam upaya mencegah dan melaporkan emisi karbon. Berdasarkan uraian tersebut maka dirumuskan hipotesis sebagai berikut :

\section{H3: Profitabilitas berpengaruh positif terhadap pengungkapan emisi karbon.}

\section{Leverage dan Pengungkapan Emisi Karbon}

Leverage diartikan sebagai tingkat ketergantungan perusahaan terhadap hutang dalam membiayai aset perusahaan maupun kegiatan operasinya (Sembiring, 2003). Tingkat leverage suatu perusahaan dapat menggambarkan resiko keuangan perusahaan. Manajemen perusahaan dengan tingkat leverage tinggi akan melakukan pengurangan pengungkapan tanggung jawab lingkungan yang terkait dengan emisi karbon agar tidak menjadi sorotan bagi para debtholders(Suhardjanto dan Choiriyah, 2010). Perusahaan yang leverage nya tinggi akan lebih fokus dalam melakukan pelunasan kewajiban daripada melakukan pengungkapan sukarela. Hal tersebut disebabkan karena terbatasnya alokasi dana yang dimiliki perusahaan sehingga harus menentukan dana tersebut untuk pelunasan segala kewajiban atau untuk melakukan pengungkapan sukarela.

Menurut Luo et al. (2013) dalam Prafitri dan Zulaikha (2016) perusahaan dengan leverage yang tinggi akan lebih mengambil sikap berhati-hati dalam hal pengurangan dan pengungkapan terutama mengenai pengeluaran-pengeluaran yang terkait dengan tindakan pencegahan karbon. Dengan demikian, perusahaan dengan leverage yang semakin tinggi maka akan semakin kecil melakukan pengungkapan sukarela dan apabila leverage perusahaan kecil maka akan semakin besar kemungkinan perusahaan melakukan pengungkapan sukarela.

Leverage dapat mempengaruhi keuangan suatu perusahaan. Kinerja keuangan sangat sensitif bagi perusahaan karena akan berdampak pada aktivitas operasional perusahan. Menurut Sartono (2001) dalam Irwhantoko dan Basuki (2016) semakin tinggi rasio leverage maka akan semakin kurang baik bagi perusahaan karena perusahaan yang 
memiliki komposisi modal lebih banyak yang bersumber dari utang berisiko mengalami kebangkrutan apabila gagal melunasi pada saat jatuh tempo.

Berdasarkan uraian tersebut maka dirumuskan hipotesis sebagai berikut:

\section{H4: Leverage berpengaruh negatif terhadap pengungkapan emisi karbon.}

\section{Ukuran Perusahaan dan Pengungkapan Emisi Karbon}

Ukuran perusahaan dapat dilihat dari sumber daya yang dimiliki oleh suatu perusahaan. Semakin besar sumber daya yang dimiliki perusahaan maka semakin besar ukuran perusahaan tersebut (Choi et al. 2013) dalam Irwhantoko dan Basuki (2016). Ukuran perusahaan juga dapat terlihat dari jumlah aktivitas operasionalnya. Semua aktivitas operasional perusahaan tidak jarang berhubungan langsung dengan lingkungan. Disamping perusahaan melakukan aktivitas operasionalnya perusahaan juga perlu menjaga lingkungan dimana aktivitas tersebut berlangsung demi mendukung kinerjanya. Perusahaan besar memiliki tekanan dan tuntutan yang lebih besar pula dari masyarakat ketika ada kegiatan yang berhubungan langsung dengan lingkungan. Sebagai jawaban perusahaan atas tekanan tersebut, perusahaan mengungkapkan informasi mengenai kinerjanya. Perusahaan besar akan lebih mampu melakukan pengungkapan informasi pada pihak eksternal. Perusahaan yang memiliki sumber daya lebih besar memiliki potensi untuk melakukan pengungkapan emisi karbon dibandingkan perusahaan kecil.

Menurut Ghozali dan Chariri (2007) dalam Suryono dan Prastiwi (2011) perusahaan besar akan melakukan pengungkapan informasi yang lebih luas untuk menyelaraskan aktivitas perusahaan dengan norma perilaku dalam sistem sosial masyarakat sebagai bentuk legitimasi perusahaan. Perusahaan besar akan mendapat pengaruh dan aktivitas yang lebih banyak terhadap masyarakat, maka akan menjadikan para pemegang saham untuk lebih memperhatikan laporan-laporan perusahaan dalam mengumumkan informasi mengenai aktivitas lingkungan yang telah dilaksanakan (Sembiring, 2003).

Perusahaan yang semakin besar cenderung untuk melakukan pengungkapan informasi lebih luas dan banyak, sehingga semakin memungkinkan untuk melakukan praktik pengungkapan emisi karbon. Berdasarkan uraian tersebut maka dirumuskan hipotesis sebagai berikut :

\section{H5: Ukuran perusahaan berpengaruh positif terhadap pengungkapan emisi karbon.}

\section{Komite Audit dan Pengungkapan Emisi Karbon}

Komite audit adalah komite yang bertugas membantu dewan komisaris dalam melaksanakan mekanisme pengawasan terhadap manajemen (Anggraini, 2014).Penelitian yang dilakukan oleh Akhiroh dan Kiswanto (2014) menunjukkan bahwa komite audit berpengaruh terhadap pengungkapan emisi karbon. Komite audit mempunyai peran penting dalam pengawasan dan pengendalian perusahaan, termasuk dalam pengungkapan lingkungan.

Menurut Suryono dan Prastiwi (2011) melalui intensitas pertemuan menjadi salah satu proksi yang dapat mencerminkan kualitas dari komite audit.

Rapat dilakukan untuk melaksanakan koordinasi agar efektif dalam menjalankan pengawasan laporan dan pelaksanaan corporate governance perusahaan agar menjadi lebih baik. Semakin komite audit itu berkualitas maka perusahaan akan lebih mengerti arti strategis dari pengungkapan informasi dan yang diinginkan oleh stakeholder secara luas. Melalui jumlah pertemuan, komite audit akan semakin mampu mendorong manajemen untuk melaksanakan praktik pengungkapan emisi karbon sebagai media komunikasi perusahaan dengan para stakeholder untuk mendapat legitimasi melalui pelaksanaan good corporate governance. 
Semakin sering mengadakan pertemuan rapat, maka koordinasi komite audit akan semakin baik pula sehingga dapat melakukan pengawasan terhadap manajemen dengan lebih efektif dan dapat mendukung peningkatan pengungkapan informasi emisi karbon yang dilakukan oleh perusahaan.

Menurut Forker (1992) dalam Anggraini (2014) komite audit dianggap sebagai salah satu alat yang efektif untuk melaksanakan mekanisme pengawasan dan pengendalian perusahaan, sehingga dapat membantu perusahaan dalam hal pengurangan biaya agensi dan meningkatkan kualitas pengungkapan informasi perusahaan, termasuk informasi mengenai emisi karbon yang telah dihasilkan oleh perusahaan.

Berdasarkan uraian tersebut dapat dirumuskan hipotesis sebagai berikut:

H6: Komite audit berpengaruh positif terhadap pengungkapan emisi karbon.

\section{METODE PENELITIAN}

\section{Populasi dan Sampel Penelitian}

Penelitian ini menggunakan jenis data sekunder dengan populasi perusahaan yang terdaftar di Bursa Efek Indonesia atau Indonesia Stock Exchange pada periode tahun 20122016. Sumber data menggunakan annual report perusahaan yang terdapat di situs web BEI atau IDX (www.idx.co.id) dan situs web dari masing-masing perusahaan. Pengambilan sampel dalam penelitian dilakukan dengan menggunakan metode purposive sampling. Berikut ini beberapa kriteria perusahaan yang dijadikan sebagai pengambilan sampel :

1. Perusahaan yang terdaftar di BEI periode tahun $2012-2016$.

2. Perusahaan yang menyediakan data Laporan Keuangan dan Annual Report secara lengkap.

3. Perusahaan yangterdaftar pada peringkat PROPER yang tercatat pada Kementerian Lingkungan Hidup periode 2012-2016.

4. Perusahaan yang mengungkapkan emisi karbon (minimal satu kebijakan atau peraturan yang terkait dengan emisi karbon/gas rumah kaca atau mengungkapkan minimal satu item pengungkapan emisi karbon).

Berdasarkan kriteria di atas, jumlah sampel perusahaan yang tersedia untuk pengujian hipotesis yaitu 117 perusahaan.

\section{Pengukuran Variabel}

Pengungkapan emisi karbon diukur dengan menggunakan sejumlah item yang yang dikembangkan Choi et al. (2013) yang dikutip dari Jannah (2014). Untuk menguji luas item pengungkapan emisi karbon, Choi et a.l (2013) mengembangkan checklist berdasarkan lembar permintaan informasi yang disediakan CDP (Carbon Disclosure Project) dan dapat dilihat pada tabel 1. CDP adalah organisasi non-profit independen yang memiliki volume terbesar informasi perubahan iklim di dunia. Checklist berguna untuk menunjukkan tingkat pengungkapan sukarela terkait perubahan iklim dan emisi karbon yang tersedia pada laporan.

Perhitungan indeks pengungkapan emisi karbon dilakukan dengan langkah-langkah berikut ini (Choi et al., 2013) dalam Jannah (2014): 1) Memberikan skor pada setiap item pengungkapan. 2) Setiap item diberi nilai 1 sehingga apabila perusahaan mengungkapkan semua item informasi pada laporannya maka skor perusahaan tersebut adalah 18. 3) Pengungkapan emisi karbon $=(\Sigma \mathrm{di} / \mathrm{M}) \times 100 \%$. Keterangan: $\Sigma$ di $=$ total item yang diungkapkan, $\mathrm{M}=$ total item maksimal (18 item). 
Tabel 1.

Carbon Emission Disclosure Checklist

\begin{tabular}{|c|c|c|}
\hline No. & Kategori & Item \\
\hline 1. & $\begin{array}{l}\text { Perubahan Iklim : Risiko } \\
\text { dan Peluang }\end{array}$ & $\begin{array}{l}\text { CC-1 : Penilaian terhadap risiko } \\
\text { (peraturan khusus maupun umum) yang } \\
\text { berhubungan dengan perubahan iklim } \\
\text { dan tindakan yang diperoleh untuk } \\
\text { mengelola risiko tersebut. }\end{array}$ \\
\hline 2. & & $\begin{array}{l}\text { CC-2 : Penilaian saat ini (dan masa } \\
\text { depan) dari implikasi keuangan, bisnis, } \\
\text { dan peluang dari perubahan iklim. }\end{array}$ \\
\hline 3. & \multirow{7}{*}{$\begin{array}{l}\text { Emisi Gas Rumah Kaca } \\
\text { (GHG/Greenhouse Gas) }\end{array}$} & $\begin{array}{l}\text { GHG-1 : Penilaian metodologi yang } \\
\text { digunakan untuk mengukur emisi gas } \\
\text { rumah kaca (misal protocol GRK atau } \\
\text { ISO) }\end{array}$ \\
\hline 4. & & $\begin{array}{l}\text { GHG-2 : Keberadaan verifikasi eksternal } \\
\text { kuantitas emisi GRK oleh siapa dan atas } \\
\text { dasar apa. }\end{array}$ \\
\hline 5. & & $\begin{array}{l}\text { GHG-3 : Total emisi gas rumah kaca } \\
\text { (metrik ton CO2-e) yang dihasilkan. }\end{array}$ \\
\hline 6. & & $\begin{array}{l}\text { GHG-4 : Pengungkapan lingkup } 1 \text { dan } 2 \text {, } \\
\text { atau } 3 \text { emisi gas rumah kaca secara } \\
\text { langsung. }\end{array}$ \\
\hline 7. & & $\begin{array}{l}\text { GHG-5 : Pengungkapan emisi GRK } \\
\text { berdasarkan sumbernya (misal: batu } \\
\text { bara, listrik, dan lain-lain). }\end{array}$ \\
\hline 8. & & $\begin{array}{l}\text { GHG-6: Pengungkapan emisi gas rumah } \\
\text { kaca berdasarkan fasilitas atau level } \\
\text { segmen. }\end{array}$ \\
\hline 9. & & $\begin{array}{l}\text { GHG-7: Perbandingan emisi } \text { GRK } \\
\text { dengan tahun-tahun sebelumnya. }\end{array}$ \\
\hline 10. & \multirow{3}{*}{$\begin{array}{l}\text { Konsumsi } \\
\text { (EC/Energy } \\
\text { Consumption) }\end{array}$} & $\begin{array}{l}\text { EC-1 : Jumlah energi yang dikonsumsi } \\
\text { (contohnya tera-joule atau PETA-joule). }\end{array}$ \\
\hline 11. & & $\begin{array}{l}\text { EC-2: Kuantifikasi energi yang } \\
\text { digunakan dari sumber daya yang dapat } \\
\text { diperbaharui. }\end{array}$ \\
\hline 12. & & $\begin{array}{l}\text { EC-3: Pengungkapan menurut jenis, } \\
\text { fasilitas atau segmen. }\end{array}$ \\
\hline 13. & \multirow{2}{*}{$\begin{array}{l}\text { Pengurangan } \text { Gas } \\
\text { Kaca dan }\end{array}$} & $\begin{array}{l}\text { RC-1: Rincian dari rencana atau strategi } \\
\text { untuk mengurangi emisi GRK. }\end{array}$ \\
\hline 14. & & $\begin{array}{l}\text { RC-2: Spesifikasi dari target level dan } \\
\text { tahun pengurangan emisi GRK. }\end{array}$ \\
\hline
\end{tabular}




\begin{tabular}{|c|c|c|}
\hline 15. & & $\begin{array}{l}\text { RC-3: Pengurangan emisi dan biaya atau } \\
\text { tabungan (costs or savings) yang dicapai } \\
\text { saat ini sebagai akibat dari rencana } \\
\text { pengurangan emisi karbon. }\end{array}$ \\
\hline 16. & & $\begin{array}{l}\text { RC-4: Biaya emisi masa depan yang } \\
\text { diperhitungkan dalam perencanaan } \\
\text { belanja modal (capital expenditure } \\
\text { planning). }\end{array}$ \\
\hline 17. & $\begin{array}{l}\text { Akuntabilitas } \quad \text { Emisi } \\
\text { Karbon }\end{array}$ & $\begin{array}{l}\text { AEC-1: Indikasi dimana dewan komite } \\
\text { (atau badan eksekutif lainnya) memiliki } \\
\text { tanggung jawab atas tindakan yang } \\
\text { berkaitan dengan perubahan iklim. }\end{array}$ \\
\hline 18. & $\begin{array}{l}\text { (AEC/Accountability of } \\
\text { Emission Carbon) }\end{array}$ & $\begin{array}{l}\text { AEC-2: Deskripsi mekanisme dimana } \\
\text { dewan (atau badan eksekutif lainnya) } \\
\text { meninjau kemajuan perusahaan } \\
\text { mengenai perubahan iklim. }\end{array}$ \\
\hline
\end{tabular}

Sumber : Choi et al. (2013) dalam Jannah (2014)

Tipe industri merupakan industri-industri yang dibagi menjadi dua kategori kelompok yaitu industri yang intensif dalam menghasilkan emisi karbon dan industri non intensif dalam menghasilkan emisi karbon. Dalam penelitian ini tipe industri diukur dengan memakai variabel dummy yakni nilai 1 untuk perusahaan yang termasuk dalam industri yang intensif dalam menghasilkan emisi yang terdiri dari energi, transportasi, bahan baku (materials) dan utilitas berdasarkan Global Industry Classification Standard (GICS) dan nilai 0 untuk perusahaan seperti jasa, keuangan, perdagangan, dll.

Kinerja lingkungan berkaitan dengan seberapa baik organisasi mengelola aspek lingkungan dari aktivitas, produk, jasa serta dampaknya terhadap lingkungan (Jannah, 2014). Kinerja lingkungan diukur dengan menggunakan PROPER. Menurut Nugraha (2015) PROPER adalah program penilaian peringkat kinerja perusahaan dalam pengelolaan lingkungan yang dikembangkan oleh Kementerian Lingkungan Hidup. PROPER adalah bentuk upaya Kementerian Negara Lingkungan Hidup untuk memajukan penaatan perusahaan dalam mengelola lingkungan hidup melalui instrumen informasi (menlh.go.id). PROPER tersebut mencakup pemeringkatan perusahaan dalam 5 warna yakni: Emas (sangat sangat baik dengan skor 5), Hijau (sangat baik, dengan skor 4), Biru (baik, dengan skor 3), Merah (buruk, dengan skor 2), Hitam (sangat buruk, dengan skor 1).

Profitabilitas dapat diukur dengan membandingkan antara pengembalian atas aset (ROA) (Freedman dan Jaggi, 2005).Dalam penelitian ini, variabel profitabilitas diukur dengan menggunakan ROA.ROA dirumuskan dengan laba bersih dibagi dengan total aset.Informasi laba bersih dapat dilihat melalui laporan laba rugi komprehensif perusahaan dan informasi mengenai total aset terdapat di laporan posisi keuangan konsolidasi perusahan.

Leverage dapat diartikan sebagai tingkat ketergantungan perusahaan terhadap hutang dalam membiayai aset perusahaan maupun kegiatan operasinya (Sembiring, 2003).Variabel leverage dihitung dengan menggunakan rumus total hutang dibagi dengan total aset.

Ukuran perusahaan merupakan suatu skala dimana dapat dikategorikan besar kecil perusahaan dengan dihitung berdasarkan total aset, penjualan, total tenaga kerja, nilai kapitalisasi pasar, dan lain-lain yang dimiliki oleh perusahaan (Suhardjanto dan Choiriyah, 
2008). Ukuran perusahaan dalam penelitian ini diukur dengan menggunakan proksi logaritma natural (ln) dari total aset perusahaan (Irwanthoko, 2016).

Menurut Suryono dan Prastiwi (2011) melalui intensitas pertemuan menjadi salah satu proksi yang dapat mencerminkan kualitas dari komite audit. Variabel komite audit dalam penelitian ini diukur dari jumlah pertemuan komite audit pada laporan tahunan perusahaan.

\section{Model Regresi}

Model yang digunakan untuk menguji pengaruh tipe industri, kinerja lingkungan, profitabilitas, leverage, ukuran perusahaan dan komite audit terhadap pengungkapan emisi karbon adalah sebagai berikut:

\section{PEK $=\beta_{0}+\beta_{1}$ Tipe_Ind $+\beta_{2}$ Kinerj_Ling $+\beta_{3}$ PROF $+\beta_{4} L e v+\beta$ - $5 i z e+$ B6Komt_Audt + e}

Keterangan: $\mathrm{PEK}=$ Pengungkapan emisi karbon; Tipe_Ind= Tipe Industri; Kinerj_Ling = Kinerja Lingkungan; $\mathrm{PROF}=$ Profitabilitas; Lev= Leverage; Size = Ukuran Perusahaan; Komt_Audt= Komite Audit.

\section{HASIL DAN PEMBAHASAN}

Bagian ini akan membahas tentang statistik deskriptif pada penelitian ini. Data awal dalam penelitian ini sebanyak 117 data perusahaan. Setelah melakukan uji asumsi klasik data yang lolos uji sebanyak 72 data perusahaan. Berdasarkan tabel 2. dapat dilihat bahwa variabel pengungkapan emisi karbon (PEK) memiliki nilai minimum sebesar 0,056 yaitu PT Astra Agro Lestari Tbk sebuah perusahaan perkebunan kelapa sawit sedangkan nilai maksimum sebesar 0,333 yaitu PT Perusahaan Gas Negara Tbk perusahaan pada bidang gas bumi. Nilai rata-rata sebesar 0,129 dengan nilai deviasi standar sebesar 0,086. Nilai rata-rata sebesar 0,129 menunjukkan bahwa rata-rata perusahaan melakukan pengungkapan emisi karbon sebesar 13\% dari 18 item checklist emisi karbon.

Tabel 2.

StatistikDeskriptif

\begin{tabular}{|l|r|r|r|r|r|}
\hline & $\mathrm{N}$ & Minimum & Maximum & Mean & $\begin{array}{c}\text { Std. } \\
\text { Deviation }\end{array}$ \\
\hline PEK & 72 & 0,056 & 0,333 & 0,129 & 0,086 \\
\hline Tipe_Ind & 72 & 0,000 & 1,000 & 0,917 & 0,278 \\
\hline Kinerj_Ling & 72 & 2,000 & 5,000 & 3,292 & 0,638 \\
\hline Prof & 72 & $-0,061$ & 0,237 & 0,065 & 0,072 \\
\hline Lev & 72 & 0,003 & 0,919 & 0,437 & 0,198 \\
\hline Size & 72 & 22,837 & 33,134 & 30,015 & 1,498 \\
\hline Komt_Audt & 72 & 3,000 & 57,000 & 13,375 & 11,751 \\
\hline
\end{tabular}

Variabel tipe industri (Tipe_Ind) ini diukur dengan menggunakan variabel dummy dimana nilai 1 untuk perusahaan yang termasuk dalam industri yang intensif dalam menghasilkan emisi seperti pertambangan, transportasi, agriculture dan manufaktur sedangkan nilai 0 untuk jenis perusahaan yang bergerak pada bidang jasa, keuangan, perdagangan, dan lain-lain. Nilai rata-rata sebesar 0,9017 serta deviasi standar sebesar 0,278. Nilai rata-rata sebesar 0,9017 menggambarkan bahwa sebanyak 90,1\% perusahaan termasuk dalam industri 
yang intensif menghasilkan emisi yaitu perusahaan yang bergerak dibidang energi, transportasi, bahan baku (materials) dan utilitas.

Variabel kinerja lingkungan (Kinerj_Ling) ini diukur menggunakan PROPER yang mencakup pemeringkatan perusahaan dalam 5 warna yakni emas (sangat sangat baik dengan skor 5), hijau (sangat baik dengan skor 4), biru (baik dengan skor 3), merah (buruk dengan skor 2) hitam (sangat buruk dengan skor 1) pada sampel tidak terdapat skor 1 karena sampel banyak yang tereliminasi. Nilai minimum sebesar 2,000 yaitu PT Fajar Surya Wisesa perusahaan yang memproduksi kertas dan nilai maksimum sebesar 5,000 yaitu PT Medco Energi Internasional Tbk sebuah perusahaan unit usaha energi. Nilai rata-rata sebesar 3,292 serta deviasi standar sebesar 0,638. Nilai rata-rata sebesar 3,292 menunjukkan bahwa sampel perusahaan dalam penelitian ini rata-rata mendapat penilaian peringkat yang baik yakni peringkat biru PROPER.

Variabel profitabilitas (Prof) memiliki nilai minimum sebesar -0,061 yaitu PT Bakrie Sumatera Plantations Tbk dan nilai maksimum sebesar 0,237 yaitu PT Multi Bintang Indonesia Tbk serta nilai rata-rata sebesar 0,065 dan nilai deviasi standar sebesar 0,072. Menurut Lukviarman (2006) dalam Pasaribu (2015) rata-rata standar rasio industri profitabilitas untuk ROA karena pada penelitian ini menggunakan rasio ROA yakni sebesar 5,98\%. Dilihat dari nilai rata-rata sebesar $6,5 \%$, nilai tersebut diatas dari standar ROA yang menunjukkan bahwa kinerja keuangan perusahaan dalam kondisi baik.

Variabel leverage (Lev) memiliki nilai rata-rata sebesar 0,437 dengan deviasi standar sebesar 0,198 serta nilai minimum sebesar 0,003 yaitu PT Austindo Nusantara Jaya Tbk dan nilai maksimal sebesar 0,919 yaitu PT Bakrie Sumatera Plantations Tbk. Menurut Kasmir (2008) dalam Pasaribu (2015) standar industri untuk rasio penelitian ini yakni menggunakan rasio debt to asset adalah sebesar 35\%. Dari nilai rata-rata sebesar 43,7\% menunjukkan bahwa nilai tersebut di atas standar industri. Semakin rendah rasio maka akan semakin baik keadaan keuangan suatu perusahaan.

Variabel ukuran perusahaan (Size) yang pengukurannya menggunakan Ln dari total aset perusahaan memiliki nilai minimum sebesar 22,837 (Rp 8.275.873.611) yaitu PT Adaro Energy Tbk sedangkan nilai maksimum sebesar 33,134 (Rp 245.435.000.000.000) yaitu PT ASTRA International Tbk dan nilai rata-rata sebesar 30,015 serta deviasi standar sebesar 1,498. Nilai standar deviasi sebesar 1,498 yang lebih rendah dari nilai rata-rata variabel menggambarkan bahwa data pada sampel penelitian untuk variabel ukuran perusahaan masih kurang bervariasi.

Variabel komite audit (Komt_Audt) dalam penelitian ini diukur dari jumlah pertemuan atau rapat komite audit memiliki nilai minimum sebesar 3 dan nilai maksimal sebesar 57 serta nilai rata-rata sebesar 13,375 dan deviasi standar sebesar 11,751. Nilai rata-rata sebesar 13,375 menunjukkan bahwa rata-rata perusahaan mengadakan pertemuan atau rapat komite audit kurang lebih sebanyak 13 kali.

\section{Pengujian Hipotesis}

Pengujian hipotesis dilakukan setelah semua asumsi klasik terpenuhi untuk mengetahui pengaruh variabel independen terhadap variabel dependen. Tabel 3 menunjukkan hasil regresi berganda untuk pengujian hipotesis. Berdasarkan tabel 3 dapat diketahui bahwa hipotesis pertama yang menghubungkan tipe industri dan pengungkapan emisi karbon berpengaruh signifikan sebesar $0,000<0,05$ terhadap pengungkapan emisi karbon dan nilai beta sebesar 0,227 dengan arah negatif tersebut tidak sesuai dengan arah yang telah diprediksikan. Hipotesis pertama memprediksi hubungan antara tipe industri dengan pengungkapan emisi karbon berhubungan positif namun hasil analisis regresi menunjukkan arah negatif sehingga hipotesis pertama ditolak. Dengan demikian, secara statistik dapat disimpulkan bahwa tipe industri berpengaruh negatif terhadap pengungkapan emisi karbon artinya perusahaan dengan tipe 
industri yang intensif menghasilkan emisi lebih kecil dalam melaporkan pengungkapan emisi karbon.

Tabel 3.

Hasil Analisis Regresi

\begin{tabular}{|l|r|l|l|}
\hline \multicolumn{1}{|c|}{ Variabel } & $\begin{array}{c}\text { Koefisien } \\
\text { Beta }\end{array}$ & Sig. & Sig./2 \\
\hline Tipe_Ind & $-0,227$ & 0,000 & 0,000 \\
Kinerj_Ling & 0,256 & 0,000 & 0,000 \\
Prof & $-0,208$ & 0,002 & 0,001 \\
Lev & $-0,055$ & 0,358 & 0,179 \\
Size & 0,258 & 0,000 & 0,000 \\
Komt_Audt & 0,781 & 0,000 & 0,000 \\
\hline
\end{tabular}

Perusahaan dengan tipe industri yang intensif dalam menghasilkan emisi dalam melaporkan pengungkapan emisi karbon belum sepenuhnya menjalankan peraturan pemerintah terkait pelaporan emisi karbon. Hal ini dikarenakan pengungkapan emisi karbon masih bersifat sukarela. Industri yang intensif menghasilkan emisi rendah dalam pengungkapan emisi karbon akan menjadi sorotan bagi pemerintah maupun komunitas dari berbagai bidang sosial dan lingkungan sehingga mengakibatkan citra perusahaan menjadi buruk.

Berdasarkan hasil pengujian hipotesis kedua, terdapat hubungan positif signifikan antara kinerja lingkungan dengan pengungkapan emisi karbon. Kesimpulan tersebut dapat diketahui dari nilai signifikan sebesar $0,000<0,05$ untuk variabel kinerja lingkungan dengan nilai beta positif yang berarti bahwa hipotesis kedua dalam penelitian ini diterima. Variabel kinerja lingkungan berpengaruh positif terhadap pengungkapan emisi karbon, semakin tinggi kinerja lingkungan suatu perusahaan maka akan semakin meningkatkan perusahaan dalam melakukan kegiatan pengungkapan emisi karbon.

Hasil penelitian ini mendukung penelitian yang dilakukan oleh Dawkins dan Fraas(2011) yang menunjukkan bahwa kinerja lingkungan memiliki hubungan positif terhadap pengungkapan lingkungan yakni terkait emisi gas rumah kaca yang didalamnya termasuk emisi karbon. Perusahaan dengan kinerja lingkungan yang rendah tidak akan mengungkapkan informasi untuk penghindaran dari paparan negatif, sedangkan perusahaan dengan kinerja lingkungan yang baik akan membedakan diri dengan mengungkapkan informasi secara sukarela mengenai kinerja perusahaan mereka. Informasi yang diungkapkan oleh perusahaan dapat memberikan keuntungan bagi perusahaan karena dapat meningkatkan nilai perusahaan.

Berdasarkan hasil pengujian hipotesis ketiga, variabel profitabilitas berpengaruh signifikan sebesar 0,001 $<0,05$ terhadap pengungkapan emisi karbon dan nilai beta sebesar 0,208 dengan arah negatif tersebut tidak sesuai dengan arah yang telah diprediksikan. Hipotesis ketiga memprediksi hubungan antara profitabilitas dengan pengungkapan emisi karbon berhubungan positif namun hasil analisis regresi menunjukkan arah negatif sehingga hipotesis ketiga ditolak. Dengan demikian, secara statistik dapat disimpulkan bahwa profitabilitas berpengaruh negatif terhadap pengungkapan emisi karbon yang artinya semakin tinggi profitabilitas perusahaan maka pengungkapan terkait emisi karbon yang dihasilkan oleh perusahaan akan semakin rendah.

Perusahaan dengan laba yang tinggi hanya memprioritaskan untuk kepentingan operasional saja, namun dalam pemanfaatan untuk aktivitas sosial dan lingkungan lebih rendah. Perusahaan dengan profitabilitas yang tinggi, lebih rendah dalam melakukan pengungkapan emisi karbon yang telah dihasilkan karena perusahaan lebih memfokuskan pada laba 
semata.Perusahaan dengan profitabilitas tinggi lebih cenderung mengutamakan kepentingan ekonomi dibandingkan kepentingan lingkungan. Perusahaan hanya berusaha mencari laba yang sebesar-besarnya tanpa mempedulikan kualitas lingkungan yang ada disekitarnya. Perusahaan dengan kinerja keuangan yang baik hanya fokus untuk mencapai tujuan keuangan saja, sebaliknya perusahaan dengan profitabilitas yang rendah akan mengambil keuntungan dalam mengungkapkan emisi karbon untuk tujuan mendapatkan legitimasi dan menunjukkan bahwa aktivitas perusahaan sudah sesuai dengan norma dan nilai sosial yang berlaku di masyarakat.

Berdasarkan hasil pengujian hipotesis keempat, variabel leverage memiliki nilai signifikan sebesar $0,179>0,05$ dengan nilai beta sebesar -0,055. Hipotesis keempat memprediksi hubungan antara leverage dengan pengungkapan emisi karbon berhubungan negatif namun hasil analisis regresi menunjukkan nilai signifikansi lebih dari 0,05 sehingga hipotesis ketiga ditolak. Dengan demikian secara statistik dapat disimpulkan bahwa leverage tidak berpengaruh terhadap pengungkapan emisi karbon.

Tingkat kinerja keuangan suatu perusahaan tidak selalu menjadi tolak ukur dalam pertimbangan melakukan pengungkapan emisi karbon. Perusahaan dengan tingkat utang tinggi ingin mendapatkan profit yang tinggi namun rendah dalam pengungkapan tanggung jawab sosial seperti emisi karbon yang telah dihasilkan karena hanya mementingkan laba semata tanpa memperhatikan kualitas lingkungan sekitar. Besar kecilnya leverage perusahaan tidak mempengaruhi pengungkapan emisi karbon.Terdapat perusahaan dengan leverage yang tinggi tidak melakukan pengungkapan emisi karbon secara luas dan ada perusahaan yang leveragenya rendah melakukan pengungkapan emisi karbon secara luas dan lengkap.

Berdasarkan hasil pengujian hipotesis kelima, terdapat hubungan positif signifikan antara ukuran perusahaan dengan pengungkapan emisi karbon. Kesimpulan tersebut dapat diketahui dari nilai signifikan sebesar $0,000<0,05$ untuk variabel ukuran perusahaan dengan nilai beta sebesar 0,258 yang berarti bahwa hipotesis kedua dalam penelitian ini diterima.

Variabel ukuran perusahaan berpengaruh positif terhadap pengungkapan emisi karbon, semakin besar ukuran perusahaan maka akan semakin meningkatnya perusahaan dalam melakukan kegiatan pengungkapan emisi karbon. Hasil penelitian ini mendukung penelitian dari Nurdiawansyah (2017) yang menyatakan bahwa ukuran perusahaan berpengaruh signifikan terhadap pengungkapan emisi karbon. Penelitian Ghozali dan Chariri (2007) dalam Suryono dan Prastiwi (2011) menyatakan bahwa perusahaan besar akan melakukan pengungkapan informasi yang lebih luas untuk menyelaraskan aktivitas perusahaan dengan norma perilaku dalam sistem sosial masyarakat sebagai bentuk legitimasi perusahaan. Dengan demikian, perusahaan besar akan lebih responsif dan meningkatkan pengungkapan informasi emisi karbon agar menjadi nilai tambah bagi citra sosial perusahaan sebagai bagian dari strategi bisnisnya.

Berdasarkan hasil pengujian hipotesis keenam, dapat diketahui nilai signifikansi sebesar $0,000<0,05$ untuk variabel komite audit dengan nilai beta sebesar 0,781 yang berarti bahwa hipotesis keenam diterima. Penelitian ini memberikan bukti adanya hubungan positif signifikan antara frekuensi rapat komite audit dengan pengungkapan emisi karbon. Hal tersebut menunjukkan bahwa semakin sering komite audit mengadakan pertemuan atau rapat maka akan semakin tinggi pula perusahaan dalam mengungkapkan emisi karbon.

Penelitian ini mendukung penilitian yang dilakukan oleh Akhiroh dan Kiswanto (2014) yang menyatakan bahwa komite audit berpengaruh terhadap pengungkapan emisi karbon.Semakin tinggi jumlah rapat atau pertemuan komite audit maka semakin tinggi pula kemungkinan perusahaan melakukan pengungkapan emisi karbon karena pengawasan menjadi lebih efektif. Keberadaan komite audit dapat membantu pengungkapan informasi yang terjamin dan sistem pengendalian perusahaan dapat berjalan dengan baik.

Dalam penelitian Suryono dan Prastiwi (2011) melalui intensitas pertemuan menjadi salah satu proksi yang dapat mencerminkan kualitas dari komite audit. Rapat dilakukan untuk 
melaksanakan koordinasi agar efektif dalam menjalankan pengawasan laporan dan pelaksanaan corporate governance perusahaan agar menjadi lebih baik. Melalui jumlah pertemuan, komite audit akan semakin mampu mendorong manajemen untuk melaksanakan praktik pengungkapan emisi karbon sebagai media komunikasi perusahaan dengan para stakeholder untuk mendapat legitimasi melalui pelaksanaan good corporate governance.

\section{KESIMPULAN}

Penelitian ini bertujuan untuk menguji faktor-faktor yang mempengaruhi pengungkapan emisi karbon yang meliputi tipe industri, kinerja lingkungan, profitabilitas, leverage, ukuran perusahaan dan komite audit dengan mengambil sampel perusahaan yang terdaftar dalam BEI pada periode tahun 2012-2016.

Hasil analisis regresi menunjukkan bahwa kinerja lingkungan, ukuran perusahaan dan komite audit berpengaruh positif terhadap pengungkapan emisi karbon. Lalu, tipe industri dan profitabilitas berpengaruh negatif terhadap pengungkapan emisi karbon, sedangkan leverage tidak berpengaruh terhadap pengungkapan emisi karbon.

\section{DAFTAR PUSTAKA}

Akhiroh, T. dan Kiswanto. 2016. The Determinant Of Carbon Emission Disclosure. Accounting Analysis Journal 5 (4) 2252-6765 (2016).

Anggraeni, D. Y. 2015. Pengungkapan Emisi Gas Rumah Kaca, Kinerja Lingkungan dan Nilai Perusahaan. Jurnal Akuntansi dan Keuangan Indonesia, 12 (2), 188-209.

Budianta, D. 2010. Pentingnya Etika Lingkungan Untuk Meminimalkan Global Warming, 110.

Choi, B., D.Lee, J. Psaror. 2013. An Analysis of Australian Company Carbon Emission Disclosure. Pacific Accounting Review 25.

Clarkson, P. M., Y. Li., G. D. Richardson., and F. P. Vasvari. 2008. Revisiting the relation between environmental performance and environmental disclosure: An empirical analysis. Accounting, Organizations and Society,33(4-5), 303-327.

Dawkins, C. and J. W. Fraas. 2011. Coming Clean: The Impact of Environmental Performance and Visibility on Corporate Climate Change Disclosure.Journal of Business Ethics, 100(2), 303-322.

Irwhantoko, I., dan B. Basuki. 2016. Carbon Emission Disclosure: Studi pada Perusahaan Manufaktur Indonesia. Jurnal Akuntansi Dan Keuangan, 18(2), 92-104.

Jannah, R. dan M. Muid. 2014. Analisis Faktor-Faktor yang Mempengaruhi Carbon Emission Disclosure Perusahaan di Indonesia (Studi Empiris pada Perusahaan yang Terdaftar di Bursa Efek Indonesia Periode 2010-2012 ). Journal Of Accounting, 3(2), 1-11. 
Nugraha, D. E. B. 2015. Pengaruh Ukuran Perusahaan, Tipe Industri, Profitabilitas, Leverage, dan Kinerja Lingkungan terhadap Environmental Disclosure, Skripsi, Program Sarjana Fakultas Ekonomi Universitas Diponegoro.

Nurdiawansyah. 2017. Determinan Pengungkapan Emisi Karbon Pada Perusahaan Manufaktur di Indonesia, Tesis, Program Magister Ilmu Akuntansi Universitas Lampung.

Pasaribu, E. J. V. 2015. Pengaruh Current Ratio (CR), Debt to Equity Ratio (DER) dan Total Assets Turnover (TAT) Terhadap Return On Assets (ROA) (Studi Pada Industri Barang Konsumsi Yang Terdaftar di Bursa Efek Indonesia), Laporan Akhir, Jurusan Akuntansi Politeknik Negeri Sriwijaya.

Perpres No. 61 tahun 2011 mengenai Rencana Aksi Nasional Penurunan Emisi Gas Rumah Kaca.

Perpres No. 71 tahun 2011 mengenai Penyelenggaraan Inventarisasi Gas Rumah Kaca Nasional.

Pradini H. S. 2013. The Analysis of Information Content towards Greenhouse Gas Emissions Disclosure in Indonesia Companies, Tesis, Program Studi Magister Fakultas Ekonomika dan Bisnis Universitas Diponegoro.

Prafitri, A., dan Zulaikha. 2016. Analisis Pengungkapan Emisi Gas Rumah Kaca. Jurnal Akuntansi Dan Auditing, 13(1), 94-114.

Pratiwi, P. C., dan V. F. Sari,. 2016. Pengaruh Tipe Industri, Media Exposure dan Profitabilitas terhadap Carbon Emission Disclosure. Jurnal WRA, 4(2), 829-844.

Sembiring, E. R. 2003. Pengaruh Karakteristik Perusahaan Terhadap Pengungkapan Tanggung Jawab Sosial: Study Empiris Pada Perusahaan yang Tercatat (Go-public) di Bursa Efek Jakarta, Thesis, Program Studi Magister Sains Akuntansi Universitas Diponegoro.

Suhardjanto, D. dan U. Choiriyah. 2010. Information Gap: Demand Supply Environmental Disclosuredi Indonesia. Jurnal Keuangan Dan Perbankan, 14(1), 36-51.

Suryono, H. dan A. Prastiwi. 2011. Pengaruh Karakteristik Perusahaan dan Corporate Governance Terhadap Praktik Pengungkapan Sustainability Report (SR): Studi pada Perusahaan-Perusahaan yang Listed (Go-Public) di Bursa Efek Indonesia (BEI) periode 2007-2009. Simposium Nasional Akuntansi XIV Aceh 2011, 21-22. 